Poznań

Cornelius CAPPELEN ${ }^{1}$

Bergen, Norwegia

\title{
Migracja wewnętrzna w UE oraz EOG a problem nielegalnego rynku pracy. Analiza sytuacji imigrantów z Polski zamieszkujących okręg Hordaland
}

\begin{abstract}
Streszczenie: Niniejsze opracowanie jest wynikiem pracy międzynarodowego zespołu badawczego i dotyczy funkcjonowania Polaków na nielegalnym rynku pracy w Norwegii. Badania zostały oparte na wywiadach pogłębionych, przeprowadzonych wśród imigrantów z Polski, zamieszkujących okręg Hordaland, którego centrum administracyjnym jest miasto Bergen. Ukazuje ono charakter tego rynku pracy oraz zasady i motywy funkcjonujących na nim pracowników z Polski.
\end{abstract}

Słowa kluczowe: migracja zarobkowa, Polacy w Norwegii, undeclared work, black labor, the black economy, informal employment

\section{Wprowadzenie}

D aństwa Nordyckie stały się atrakcyjnym miejscem pracy oraz nowego osiedlenia obywateli RP, a mała, niespełna 5 milionowa Norwegia czwartym krajem emigracji Polaków po Wielkiej Brytanii, Irlandii oraz Niemczech. Wszystko wskazuje na to, iż z uwagi na atrakcyjność rynku pracy oraz warunki socjalne oferowane na takich samych zasadach jak dla Norwegów, może dojść do dalszej intensyfikacji migracji. Już dzisiaj Polacy w Norwegii stanowią drugą grupę narodowościową po Norwegach w tym państwie.

Nie ulega wątpliwości, iż migracja na tak dużą skalę powoduje określone konsekwencje zarówno dla państw i społeczeństw przyjmujących imigrantów, jak i ich pochodzenia. Jedną z bardzo ważnych kwestii jest badanie efektów migracyjnych z perspektywy konsekwencji społeczno-ekonomicznych, w tym istniejących relacji dotyczących rynków pracy. Jednym ze zjawisk funkcjonujących na tych rynkach jest praca nierejestrowana tzw. ,praca na czarno”.

${ }^{1}$ Autorzy i Nina Berven, Stein Kuhnle, Kjetil Lundberg, Ragnhild Louise Murrias to członkowie zespołu uczestniczącego w Projekcie 227048 finansowanym przez Research Council of Norway w ramach programu: Research Programme on Welfare, Working Life and Migration - VAM 2009-2018, tytuł: Labor migration and the moral sustainability of the Norwegian welfare state, przygotowujący pytania badawcze, opracowujący metodologię badań, współuczestniczący w przeprowadzaniu wywiadów. Wyniki tych badań zostały wykorzystane w opracowaniu tego artykułu. 


\section{Metodologia badań}

Podstawą niniejszego artykułu są badania podjęte przez międzynarodowy zespół badawczy realizujący projekt Labour migration and the moral sustainability of the Norwegian welfare state finansowany przez Research Council of Norway, w ramach programu Welfare, Working Life and Migration (Velferd, Arbeidsliv og Migrasjon - VAM). Kierownikiem Projektu jest Profesor Stein Kuhnle, Department of Comparative Politics, University of Bergen, natomiast częścią badawczą dotyczącą Polaków kieruje Profesor Wojciech Nowiak². The primary objective of the research project is to examine how labour migration affects various aspects of the welfare state and the organization of labour life.

Podstawę metodologiczno-teoretyczną zespołu stanowią metody komparatystyczne - comparative politics (Landman, Robinson, 2009). Badania dotyczące imigrantów prowadzone zostały przy użyciu metod zarówno ilościowych - analizy danych statystycznych, jak i jakościowych - badania przy użyciu metody wywiadu pogłębionego (Weiss, 1995; Kvale, Brinkmann, 2009). Najczęstszą barierą w tego typu interkulturowych badaniach są możliwości komunikacyjne, zostały one przełamane poprzez fakt funkcjonowania w zespole badaczy z Polski. Uczestniczący bezpośrednio w opracowaniu podstaw metodologicznych oraz w przeprowadzeniu wywiadów Wojciech Nowiak - posługujący się biegle językiem polskim, norweskim oraz angielskim - sprzyjał otwartości przeprowadzanych wywiadów. Nie wystapiła konieczność korzystania z tłumaczy, zarówno na etapie dyskusji metodologicznej, jak i bezpośredniego przeprowadzenia wywiadów, w których uczestniczył kolejny badacz z Polski, Dominika Narożna.

Podjęcie próby odpowiedzi na pytanie dotyczące nielegalnego rynku pracy było możliwe dzięki wywiadom przeprowadzonym w roku 2014 - okręg Hordaland w Norwegii. Główna grupa to Polacy mieszkający i pracujący w Bergen. Pierwszy etap stanowiły, przeprowadzone na początku 2014 roku wywiady pilotażowe, uczestniczyła w nich grupa 10 Polek i Polaków. Po analizie danych pochodzących z badań pilotażowych, stworzono podstawę do badań właściwych, zostały one przeprowadzone w okresie 05-07.2015 na grupie 80 Polek i Polaków. Czas trwania wywiadów od 1 do 2,5 godziny. Analizie stanowiącej podstawy niniejszego opracowania poddano 66 wywiadów z II fazy badań, ponieważ część respondentów wycofała w późniejszym czasie swój akces uczestniczenia w opracowanych badaniach. Względy etyczne nakazały, by uszanować ich wolę, mimo wcześniejszych deklaracji i oświadczeń o dobrowolności.

W badaniu wykorzystano efekt kuli śnieżnej. W miarę wzrostu liczby osób przebadanych, nabraniu zaufania do badaczy, kolejne osoby podawały kontakty do innych respondentów. Starano się, by dobór ten był adekwatny do sytuacji Polaków na norweskim rynku pracy oraz w polskiej grupie imigrantów. Dominują na nim zawody budowlane

${ }^{2}$ W Projekcie uczestnicza: Department of Comparative Politics, University of Bergen - Prof. Stein Kuhnle; Prof. Ragnhild Louise Muriaas; Cornelius Cappelen Ph.D., Prof. Michaël Tatham, Jannike Gottschalk Ballo M.A., Prof. Tor Midtbø, Yvette Peters Ph.D.; Buskerud and Vestfold University College - Prof. Eskil Le Bruyn Goldeng; Norwegian School of Economics (NHH) - Prof. Alexander Cappelen, Prof. Bertil Tungodden; Norwegian School of Business (BI) - Prof. Amir Sasson; Uni Research Rokkan Centre - Nina Breven Ph.D., Kjetil G. Lundberg Ph.D.; Adam Mickiewicz University, Faculty of Political Science \& Journalism, Poznan - Prof. Wojciech Nowiak, Dominika Narożna Ph.D. 
oraz pokrewne, natomiast dominującą grupą są mężczyźni, w większości pracujący i zamieszkujący bez członków swoich rodzin.

Część pytań dotyczyła doświadczeń respondentów z funkcjonowaniem nierejestrowanego rynku pracy w Norwegii. Mogły one mieć charakter bezpośredni - doświadczenia osobiste lub pośredni - znajomość osób i sytuacji związanych z tym sektorem rynku pracy. Bardzo istotne było umiejętne formułowanie pytań. Używano określeń „praca na czarno”, „praca nielegalna”, „,dorabianie sobie”, „fucha”, „praca po godzinach”. Miało to być bardziej zrozumiałe, niż oficjalne określenia - „undeklared work”, „informal employment”.

Bardzo istotne było zachowanie anonimowości respondentów, na potrzeby publikacji zakodowano wszystkie imiona, stąd dziwnie brzmiąca, nie polska pisownia niektórych z nich. Wywiady były dobrowolne.

\section{Sytuacja Polaków na rynku pracy w Norwegii po przystąpieniu do UE}

Norwegia przestała być peryferyjnym, pod względem migracji, państwem Europy. W 2010 roku zarejestrowano przybyszów z ponad 200 państw świata. Norwegia stała się w tej kwestii liderem wśród wszystkich państw Norden³, wyprzedzając Szwecję czy też Danię. Bardzo istotny okazał się fakt rozszerzenia UE o grupę państw E10 (Velferd, NOU: 2011:7, s. 12). Norwegia była i jest jednym z państw EOG, które bezpośrednio po przystąpieniu w 2004 roku nowych państw członkowskich do UE odczuło efekt migracyjny. Podobnie, jak i w innych państwach europejskich, dominował tam nowy typ migracji zarobkowej. W odniesieniu do Europy Wschodniej, Norwegia stosowała kwoty specjalistów oraz przyjmowała pracowników sezonowych głównie w rolnictwie, nigdy liczba ich nie przekraczała kilku tysięcy rocznie (Brox, 2005).

W odniesieniu do 8 nowych państw członkowskich UE: Polski, Czech, Węgier, Estonii, Łotwy, Litwy, Słowacji i Słowenii w latach 2004-2009 obowiązywały przepisy przejściowe dotyczące zatrudnienia (Velferd, NOU: 2011:7, s. 71). Konsekwencje bycia członkiem EOG niosły daleko idące, bardzo korzystne zmiany, jeśli chodzi o możliwość korzystania z rozwiązań socjalnych funkcjonujących w Norwegii. Polacy z dnia na dzień stali się częścią norweskiego „welfare state” (Nowiak, 2011).

Polacy migrujący do Norwegii w celach zarobkowych wykorzystują w praktyce wszystkie możliwe formy zatrudnienia. Norwegia jest dla Polaków atrakcyjnym miejscem pracy nie tylko z uwagi na wysokość zarobków, lecz również fakt, iż nie są oni tam traktowani jak zagrożenie czy też konkurencja dla miejscowej siły roboczej (Ødegård, Andersen, 2011:21). Z uwagi na istniejące bariery o charakterze językowym, większość Polaków przyjeżdżających do Norwegii znajdowała zatrudnienie w tradycyjnych zawodach robotniczych (Frieberg, Dølvig, Eldring, 2013, s. 17).

W okresie 10 lat członkostwa (2004-2014) przyrost ilościowy dotyczący Polaków osiagnął poziom $1101 \%$, większy wzrost odnotowano jedynie w przypadku obywateli Litwy 3694\% (Aftenposten, 2014). W liczbach bezwzględnych, według danych na

${ }^{3} \mathrm{~W}$ odniesieniu do regionu, powszechnie stosowane jest określenie Norden, odnoszące się do całej grupy państw i regionów, w skład tej wspólnoty wchodzą: Dania, Finlandia, Islandia, Norwegia, Szwecja, Wyspy Alandzkie, Grenlandia oraz Wyspy Owcze. 
1 stycznia 2015 roku, imigranci oraz dzieci imigrantów z korzeniami polskimi stanowili 99400 osób, przy ogólnej liczbie 804 963. Oznaczało to, iż Polacy stanowili największą grupę przed Litwinami - 39300 oraz Szwedami - 39100 (Invandrere, 2015).

Dane dotyczące dotychczasowych imigrantów z Polski, którzy podjęli pracę w Norwegii pokazują, iż na dwoje z trzech obywateli polskich, to mężczyźni. Kobiety, Polki, które funkcjonują w tym kraju, to głównie osoby młode lub przybyłe w wyniku łączenia rodzin z ich partnerami, którzy wcześniej przybyli w celach zarobkowych. Badania prowadzone w Norwegii dotyczące imigrantów z Polski wskazują, iż większość z nich przyjechała do pracy, o którą starali się podczas pobytu w Polsce, było to wynikiem funkcjonowania polskich lub norweskich biur pracy (Friberg, Eldring, 2011:27).

Polacy, podobnie jak obywatele z innych państw grupy E10, pracowali głównie, bo aż w 77\%, w trzech sektorach gospodarki: rolnictwo, przemysł oraz budownictwo. Sytuacja ta zmieniła się nieco po roku 2010, gdy do Norwegii zaczęły przybywać kobiety i podejmować pracę zarobkową (Friberg, Eldring, 2011:27, s. 22). Pozostałe branże to usługi sprzatające, handel, transport, hotelarstwo, gastronomia oraz usługi publiczne, między innymi zdrowotne oraz socjalne. Jeśli chodzi o kobiety, to w zdecydowanej większości znajdują one początkowe zatrudnienie w branży sprzątającej, na podstawie prywatnych zleceń dotyczących gospodarstw domowych. Jest to niewatpliwie związane $\mathrm{z}$ bariera językową, kobiety nie pracują $\mathrm{w}$ dużych grupach, takich $\mathrm{w}$ jakich $\mathrm{w}$ branży budowlanej funkcjonują mężczyźni, w związku z powyższym znajomość języka jest dla nich niezbędnym warunkiem uzyskania innej pracy. Badania przeprowadzone w Norwegi dotyczące Polaków pracujących w Oslo wskazują, iż w głównych branżach, jakimi są sektor budowlany oraz czystości (firmy sprzątające) są oni głównie pracownikami podnajmowanymi.

\section{Polacy pracujący w okręgu Hordaland - doświadczenia z nierejestrowanym rynkiem pracy - badania wlasne}

Tak jak wspomniano na wstępie, badania objęły grupę łącznie ponad 80 osób, część $\mathrm{z}$ respondentów po przeprowadzonych wywiadach, bezpośrednio komunikując się z grupa przeprowadzającą wywiady, poprosiła o wyłączeniu ich z opracowania, co zgodnie z przyjętymi zasadami etycznymi było możliwe na każdym etapie badania. Ostatecznej analizie autor artykułu poddał 65 wywiadów. W grupie tej znalazło się 21 kobiet i 44 mężczyzn.

Pytania dotyczące pracy nierejestrowanej tzw. „na czarno” były sformułowane w taki sposób, by dać respondentom możliwość komfortowych odpowiedzi. Brzmiały one: $C z y$ kiedykolwiek pracowateś na czarno? A czy znasz kogokolwiek kto pracuje lub pracowat na czarno w Norwegii, bez podawania danych personalnych? Czy spotkałaś/eśs się ze zjawiskiem takiej pracy? Czy masz takie informacje od znajomych lub innych osób potwierdzajace ten rodzaj pracy?

Bardzo bliski kontakt $\mathrm{z}$ badanymi oraz fakt, iż nabrali oni stopniowo zaufania do przeprowadzających wywiady, którymi byli Polacy, spowodował niezwykle otwartą rozmowę na ten temat. Nie mieli oni obaw o ewentualne konsekwencje swojej szczerości. 
Nim przejdziemy do analizy poszczególnych wypowiedzi, która z racji objętości tego opracowania jest ograniczona, warto przytoczyć generalne dane. W przypadku całej badanej grupy, 29 osób jednoznacznie określiło, iż miały podczas swojego pobytu w Norwegii epizody związane z pracą na czarno. Dotyczyło to 11 kobiet oraz 28 mężczyzn. O motywach i charakterze tej pracy będzie mowa później. Jeśli chodzi o znajomość faktów pracy innych Polaków w nieoficjalnym sektorze gospodarki (the black economy), zostało to potwierdzone przez dużo większą grupę, bo aż 55 osób. W tej grupie 22 osoby były tymi, którzy sami pracowali w podobnym charakterze, a 30 osób same nie pracowały i nie miały osobiście takich doświadczeń, natomiast znały lub znają przypadki innych osób. Wśród niepracujących osobiście, natomiast znających inne osoby lub fakty, 12 to były kobiety, 18 to mężczyźni. Łącznie z wszystkich badanych 59 osób miało bezpośrednie lub pośrednie doświadczenia z nieformalnym rynkiem pracy (informal employment), co wymaga zastanowienia, mając na uwadze, iż od 2004 roku Polska jest częścią UE.

Co powoduje taką sytuację postaramy się odpowiedzieć poprzez analizę wywiadów. Z uwagi na ograniczenie objętościowe posłużymy się wybranymi wypowiedziami, bardziej szczegółowe opracowanie będzie miało wymiar monografii. Podzielimy je na cztery grupy, z uwagi na ich osobiste doświadczenia.

Pierwsza grupa - osoby pracujace kiedykolwiek na nieformalnym rynku pracy - kobiety.

Cecylja, lat 47, dwoje dzieci, rozwiedziona, zatrudniona w sektorze usług publicznych.

Jednoznacznie stwierdziła, iż pracowała na czarno około roku. Pracowała legalnie i jednocześnie sobie dorabiała, sprzątając po godzinach w firmie adwokackiej. Motywem nie był zysk tylko propozycja od samych pracodawców, którzy zaproponowali jej pracę po godzinach, nierejestrowaną bez konieczności opłacania podatków. Opłacali jej nawet koszty dojazdu do pracy środkami komunikacji miejskiej.

Justyna, 49 lat, troje dzieci, mieszka $\mathrm{z}$ rodziną w Norwegii, zatrudniona w sektorze publicznym.

Jednoznacznie stwierdziła, iż w swoich wcześniejszych doświadczeniach zawodowych pracowała na czarno, sprzątając i pilnując dzieci. Była to praca z tzw. polecenia, osoby - Norwegowie zadowoleni z pracy Justyny, polecali ją innym swoim znajomym, a ona wędrując od domu do domu dorabiała sobie dodatkową pensję. W tym samym czasie pracowała legalnie w firmie sprzątającej, wykonującej usługi dla biur oraz różnych instytucji.

Penelopa, 31 lat, samotna, bezdzietna, zatrudniona $\mathrm{w}$ sektorze gastronomicznym.

Jednoznacznie stwierdziła, iż pracowała tak przez dwa miesiące, w czasie uczęszczania na kurs językowy. Pracy poszukiwała poprzez rozmieszczanie ogłoszeń w supermarketach. Pracowała, opiekując się dziećmi oraz osobami starszymi, po uzyskaniu legalnego zatrudnienia zrezygnowała z dorabiania, z powodu braku czasu. Swoje kontakty przekazała innym Polkom.

Róża, 44 lata, troje dzieci, cała rodzina mieszka w Norwegii, zatrudniona w sektorze prywatnym - księgowość.

W początkowym okresie swojego pobytu, nie znając języka, pracowała nielegalnie sprzątając norweskie domy. Powodem nie był brak pieniędzy - jej mąż wcześniej przy- 
jechał do Norwegii i miał legalną pracę, lecz chęć robienia czegokolwiek. Jej zdaniem Norwegowie chętnie zatrudniają w ten sposób obcokrajowców, gdyż mają o 50\% tańszą usługę, niż gdyby robiły to legalnie funkcjonujące firmy.

\section{Benedykta, 31 lat, jedno dziecko, cala rodzina mieszka w Norwegii, zatrudniona w sektorze usług.}

Wykonuje swoją pracę po godzinach, pracuje jednocześnie legalnie w usługach kosmetycznych. Ma swoich stałych klientów, nie daje ogłoszeń. Główną przeszkodą w zarejestrowaniu własnych usług i legalnego odprowadzania podatków jest brak jasnych i przyjaznych przepisów. W jej ocenie możliwość legalnej działalności w tym sektorze jest dużo łatwiejsza w Polsce niż Norwegii.

Druga grupa - osoby pracujace kiedykolwiek na nieformalnym rynku pracy - mężczyźni.

Filip, wiek około 40 lat, dwoje dzieci, wspólnie z rodziną mieszka w Norwegii, zatrudniony w sektorze budowlanym.

Jednoznacznie oświadczył, iż w ciagu swojego pobytu w Norwegii około roku przepracował na czarno. Początkowo pracował legalnie, miał zarejestrowaną firmę w sektorze usług budowlanych, jednak ta firma zbankrutowała z powodu nieuregulowania płatności przez kontrahentów. Nie miał pieniędzy na podatki, musiał kontynuować działalność nielegalnie, to trwało około 1 roku. Zatrudniali go i korzystali z jego usług $\mathrm{Ci}$ sami Norwegowie, u których wcześniej wykonywał usługi legalnie, decydowała znajomość i wcześniejsze kontakty. Po ponownym podjęciu legalnej pracy zrezygnował z tej formy, pomimo wyższych dochodów. Decydującym motywem była chęć podlegania legalnym zasadom zatrudnienia.

Dominik, wiek 41 lat, dwoje dzieci z pierwszego małżeństwa, jedno z drugiego, z obecną rodziną mieszka w Norwegii, zatrudniony w sektorze usług budowlanych.

Ocenia, iż w sumie „dorabiał sobie” około 3 miesięcy. Nie wynikało to z chęci zysku, ale znajomi prosili go o to, żeby pomógł im w remontowaniu mieszkania, zgodził się na to. Nie ma potrzeby dodatkowego, nielegalnego zatrudnienia, ponieważ on oraz jego żona pracują w Norwegii legalnie i mają dobry standard życia.

Pawel, wiek 30 lat, jedno dziecko, żonaty, rodzina zamieszkuje w Polsce, zatrudniony w sektorze budowlanym.

Przyznaje, iż około 6 miesięcy pracował w nieformalnym sektorze gospodarki. Pracę wykonywał u przyszłego pracodawcy, Norwega, wykonując usługi budowlane. Był to swoistego rodzaju okres próbny - od samego początku było wiadomo, że jeżeli się sprawdzi, to dostanie stałą pracę. Paweł opowiada, iż w ten sposób rozpoczyna swoją „przygodę" z norweskim rynkiem pracy bardzo wielu Polaków. Godzą się na to, ponieważ nie mają wyboru. Jest to wymuszone przez ich potencjalnych, norweskich pracodawców.

Danek, wiek 42 lata, dwoje dzieci, żonaty, rodzina mieszka w Polsce, zatrudniony w branży budowlanej.

Przyznaje, iż na początku swojego pobytu przez około 3 miesiące pracował nielegalnie, nie miał żadnych obaw, gdyż było to powszechnie praktykowane - rok 2005. W tym okresie wszyscy jego znajomi pracowali w ten sposób, nikt się tym nie przejmował. Pierwsze dwa dni strachu, potem już rutyna. W jego ocenie nie było alternatywy, decyzja o początkowej pracy na czarno lub powrót do Polski. W chwili obecnej 
nie podejmuje i nie pojąłby się takiej pracy, ponieważ pracuje legalnie i czułby się wykorzystywany.

Patek, wiek 43 lata, dwoje dzieci, żonaty, rodzina mieszka w Polsce, zatrudniony w branży budowlanej.

Przez kilka miesięcy pracował na czarno. Było to swoistego rodzaju oszukiwanie norweskich inspektorów pracy, gdyż praca była od 16 godziny. Natomiast jak stwierdził, wszyscy wiedza, iż norwescy inspektorzy pracy nie pracują popołudniami. Po znalezieniu legalnej pracy nie pracował już w taki sposób, gdyż jest to zbyt ryzykowne i się to nie opłaca.

Trzecia grupa - osoby same niemajace takich doświadczeń, lecz znajace lub majace informacje o innych - kobiety.

Truda, wiek 55 lat, 3 dzieci, mężatka, rodzina mieszka w Norwegii, zatrudniona w sektorze usług publicznych.

Sama nie pracowała w sektorze gospodarki nieformalnej, gdyż nie było takiej potrzeby. Zna osoby zatrudnione na czarno, jest to głównie sektor budowlany oraz mechanicy samochodowi w przypadku mężczyzn. Natomiast jej zdaniem kobiety głównie pracują jako opiekunki do dzieci. Opisując motywy tych ludzi uważa, iż jest to swoistego rodzaju okres przejściowy przed uzyskaniem legalnej pracy lub chęć dorobienia sobie. Jej zdaniem pomimo ryzyka, Norwegowie bardzo chętnie zatrudniają w ten sposób, gdyż korzyści są obopólne.

Olesia, wiek 51 lat, jedno dziecko, mężatka mieszka z rodziną w Norwegii, zatrudniona w sektorze publicznym.

Od samego początku sama pracowała legalnie, pomimo wyższego wykształcenia była to na początku praca w firmie sprzątającej. Teraz pracuje zgodnie ze swoim zawodem i taka potrzeba nie występuje również teraz. Jej zdaniem większość osób pracujących w nieformalnym sektorze gospodarki to osoby remontujące domy, opiekujące się dziećmi lub sprzątające. Jej zdaniem Norwegowie biorą głównie ludzi do drobnych prac domowych, budowlanych, w ogrodzie lub remontów. Przy większych inwestycjach jest zbyt duże ryzyko związane z gwarancją itp. Pewne prace muszą być wykonywane legalnie przez oficjalne firmy, bo ryzyko jest zbyt duże - dotyczy to prywatnych inwestorów.

Zuzanna, wiek 29 lat, nie ma dzieci, wspólnie z partnerem mieszka w Norwegii, pracuje w prywatnym sektorze innowacyjnych technologii.

Od razu znalazła legalną pracę w firmie międzynarodowej, zna osoby pracujące nielegalnie. Są to głównie osoby sprzątające domy lub pracujące w usługach budowlanych. Jej zdaniem głównym powodem takiej formy pracy jest brak stałego zatrudnienia lub nieznajomość języka. Często są to kobiety mające małe dzieci, chcące sobie dorobić bez utraty świadczeń rodzinnych. W jej ocenie Norwegowie oszczędzają w ten sposób pieniądze oraz unikają obowiązków biurokratycznych - umów itp.

Celina, wiek 31 lat, dwoje dzieci, mężatka, wspólnie z mężem mieszkają w Norwegii, zatrudniona $w$ sferze usług publicznych.

Jej zdaniem nie jest osobą, która ma predyspozycje do tego typu pracy i nigdy nie miała takich ofert. Głównie zna osoby pilnujące dzieci, sprzątające domy lub remontujące domy i mieszkania. Odbywa się to w ten sposób, iż norweski inwestor kupuje materiały, znajduje nielegalnego wykonawcę i oboje na tym zyskują. Osoby wykonujące 
te prace są bezrobotne lub chcą sobie dorobić. Uważa, iż jeżeli chodzi o prace budowlane, to Polacy są tańsi i decyduje chęć oszczędzania przy ich zatrudnieniu. Natomiast jeżeli chodzi o opiekę nad dziećmi, to Polki mają renomę dobrych opiekunek, dbających o dzieci. Przy sprzątaniu można często zarobić więcej niż będąc normalnie zatrudnionym. Ona sama zna takie osoby, które zarabiają więcej od niej.

Katrin, wiek 54, jedno dziecko, rozwiedziona, prywatny przedsiębiorca.

Jak sama twierdzi, nigdy nie miała potrzeby takiej pracy, natomiast jeśli nie miałaby środków do życia, to osobiście by taką pracę podjęła. Zna bardzo wielu Polaków pracujących nielegalnie, są to głównie osoby zatrudnione w nieformalnym sektorze gospodarki (informal economy), w sektorze budowlanym. Oprócz tego jest też sprzątanie mieszkań i domów. Jej zdaniem pracę na czarno determinuje brak znajomości języka, dotyczy to zwłaszcza branży budowlanej.

Czwarta grupa - osoby same niemajqce takiego doświadczenia, lecz znajace lub majace informacje o innych - mężczyźni.

Teodor, wiek 36 lat, jedno dziecko, żonaty, rodzina przebywa w Polsce, zatrudniony w sektorze budowlanym.

Jak stwierdził, nigdy nie pracował w Norwegii na czarno i nie chciałby tego robić. Motyw jest jednoznaczny, myśli o przyszłości i o emeryturze. Zna przypadki wielu Polaków, zatrudnianych przez polskich pośredników, chcących ich w ten sposób wykorzystać i na nich dodatkowo zarobić. Jego zdaniem Norwegowie są bardziej ostrożni, boją się kontroli i konsekwencji. Zna również Polaków dorabiających sobie nielegalnie po godzinach. W jego ocenie są to prace $\mathrm{z}$ tzw. polecenia przez znajomych.

Wiktor, wiek 30 lat, 2 dzieci, żonaty rodzina przebywa w Polsce, zatrudniony jako brukarz.

Norwegia nie jest jego pierwszym miejscem pracy za granica, od samego początku pracuje tu legalnie. Zna osoby pracujące nielegalnie po 2-3 godziny dziennie, są to osoby pracujące dorywczo. W jego ocenie jest to wygodne dla Norwegów, zwłaszcza w jego branży oraz opłacalne dla Polaków, którzy nie przyjechali na wakacje i zwiedzanie, tylko do ciężkiej pracy, żeby zarobić pieniądze.

Sergiusz, wiek 41 lat, troje dzieci, żonaty, rodzina mieszka w Polsce, zatrudniony w branży budowlanej.

Od samego początku zatrudniony był legalnie. Nie interesowała go praca ,na czarno", bo nie miał na to czasu. Zna osoby tak pracujące, są to głównie ludzie chwilowo bezrobotni. Polacy są głównie zatrudniani do prac wokół domu oraz remontów. Jego zdaniem, Norwegom się to opłaca, gdyż mają dobrą i tańszą usługę, a Polacy pieniądze. Natomiast uważa, że nie zatrudniają w ten sposób firmy, gdyż jest to zbyt ryzykowne.

Linik, wiek 28 lat, bezdzietny, partnerka mieszka w Norwegii, pracuje jako konserwator $\mathrm{w}$ prywatnej posiadłości.

Sam nie pracował na czarno, nie miał takiej potrzeby i możliwości. Natomiast mówił, iż rozumie tych ludzi i gdyby sam był w sytuacji bez pracy, to zdecydowałby się na nielegalne zatrudnienie. Zna bardzo wiele osób pracujących legalnie u Norwegów i dorabiających na tzw. „fuszkach”. Norwegowie zatrudniają te osoby, ponieważ jest to dużo taniej niż zatrudnialiby do tego typu prac legalne firmy. Zarówno Polakom, jak i Norwegom się to opłaca. 


\section{Oliwjer, wiek 35 lat, dwoje dzieci, żonaty, rodzina mieszka w Polsce, zatrudnio- ny w branży budowlanej.}

Nigdy nie miał potrzeby pracy na czarno, pracował tylko legalnie, oprócz tego nie ma na taką pracę czasu. Zna osoby pracujące w ten sposób w branży budowlanej. Może to być np. wykończeniówka - ludzie do 16-tej kładą płytki legalnie, a od 17-tej nielegalnie. Są tego typu zlecenia, zarówno Norwegowie, jak i Polacy na tym zyskują.

\section{Wnioski płynące z badań imigrantów z Polski w Norwegii}

Wyniki badań, reprezentatywne przedstawienie analizy części wywiadów wskazuje, iż dzięki otwartości i dobrej współpracy z prowadzącymi badanie, udało się uzyskać bardzo wiarygodne dane oparte na osobistych doświadczeniach, a dotyczące Polaków funkcjonujących na norweskim nielegalnym rynku pracy. Blisko połowa badanych (29 osób) miała osobiste, głównie krótkookresowe lub doraźne doświadczenia na nieformalnym rynku pracy. Ponad osiemdziesiąt procent badanych (55 osób) potrafi jednoznacznie wskazać przykłady innych osób pracujących na czarno w Norwegii.

Nielegalny, nieformalny rynek pracy mężczyzn dotyczy głównie branży budowlanej - wykończanie lub remontowanie domów oraz mieszkań lub prace wokół domów - zieleń oraz szeroko rozumiane porządkowanie. Bardzo często Polacy zaczynają w ten sposób swoją pracę w Norwegii, jest to swoistego rodzaju sprawdzenie ich kwalifikacji przez norweskich pracodawców lub konieczność związana z początkowym, krótkotrwałym brakiem pracy.

Ponieważ respondentami były osoby pracujące w tym kraju od kilkunastu, a nawet kilkudziesięciu lat, widać wyraźnie, iż możliwości na wpół legalnej pracy w dużych firmach jednoznacznie zostały ograniczone poprzez możliwości kontroli oraz kar stosowanych przeciwko nieuczciwym wobec państwa przedsiębiorcom.

Bardzo prężny jest natomiast sektor drobnych usług świadczonych prywatnym inwestorom w postaci remontów domów oraz mieszkań. Jak widać, jest to praktyka powszechnie znana i akceptowana przez Norwegów. Cenią sobie oni dużo tańsze niż oficjalnie, bardzo dobrze wykonywane prace, które wykonują Polacy.

Większość badanych Polaków nie jest zainteresowana tego typu pracą na stałe, zdarza się im ona podczas krótkotrwałych kryzysów, związanych z brakiem pracy lub na zasadzie dorobienia po godzinach tzw. „fuch”.

Jak wskazuje bardzo wiele badań (Ayres, 2013) przeprowadzonych w Europie po rozszerzeniu UE o nowe państwa członkowskie, na nielegalnym rynku pracy dotyczącym kobiet jednym z dominujących sektorów obok prostytucji, są szeroko rozumiane prace domowe. Potwierdza się to w odniesieniu do prac domowych niemal w $100 \%$ kobiet, nie odnotowano natomiast ani jednego odniesienia, jeśli chodzi o przypadki prostytucji. Może to świadczyć o przejściowym charakterze pracy w nieformalnym sektorze kobiet z Polski.

Dowiodły tego również badania przeprowadzone w Norwegii. Polki pracują tam głównie jako osoby sprzątające oraz opiekunki do dzieci. Głównym powodem tego typu zatrudnienia jest początkowy brak znajomości języka oraz chęć dowartościowania, posiadania własnych pieniędzy. Polki przyjeżdżają głównie do Norwegii w wyniku 
naturalnego, stopniowego procesu łączenia rodzin lub przyjeżdżając samotnie znajdują partnerów w Norwegii.

\section{Zakończenie}

Jak wskazuje analiza wywiadów przeprowadzonych w roku 2014 w okręgu Hardaland, z jego centrum administracyjnym Bergen, członkostwo Polski w Unii Europejskiej oraz możliwość legalnej pracy w państwach Europejskiego Obszaru Gospodarczego, do których należy Norwegia, nie wyeliminowało zjawiska pracy w nieformalnym obiegu gospodarczym.

Jednak praca ta stała się głównie krótkookresowa czy wręcz dorywcza. Większość Polaków - mężczyzn pracujących w branży budowlanej, nie jest zainteresowana w podejmowaniu tego typu zatrudnienia, chyba że są do tego zmuszani przez okoliczności. Dla Polek praca ta jest w większości przypadków krótkotrwałą koniecznością z uwagi na brak znajomości języka i braku możliwości podjęcia innej pracy.

Bardzo ciekawy jest fakt, iż jak wskazują wyniki badań przedstawiane w tym artykule, prace wykonywane przez Polki oraz Polaków w Norwegii są inicjowane, a czasami nawet wymuszane przez pracodawców norweskich. Czasami można odnieść wrażenie, iż jest to praktyka powszechnie akceptowana, zwłaszcza, że dotyczy to prac domowych - sprzątanie, remontowanie domów oraz mieszkań. Jedyną barierą w tym zakresie jest brak chęci podejmowania takiej pracy przez Polaków.

\section{Bibliografia}

Aftenposten, Lørdag 26. april 2014.

Anderson B. (2000), Doing the dirty work? The global politics of domestic labour, Zed Books, London-New York.

Ayres R., Barber T., Anthias F., Cederberg M. (2013), Profiling Female Migrants in Europe: Categories of Difference, w: Ayres R., Profiling Female Migrants in Europe: Categories of Difference, Springer, s. 17-36.

Brox O. (2005), Arbeidskraftimport: velferdsstatens redning - eller undergang?, Pax, Oslo.

Castles S., Miller J. M. (2009), The age of migration: International population movements in the modern world, Palgrave Macmillan, Basingstoke.

Friberg J. H., Eldring L., Polonia i Oslo 2010. Mobilitet, arbeid og levekår blant polakker $i$ hovedstaden, Fafo-rapport 2011:27.

Frieberg J. H., Dølvig J. E., Eldring L. (2013), Arbeidsmigrasjon fra Øst-og Sentral-Europa, Temanotat, Norges forskningråd, Oslo.

Frieberg J. H., Elgvin O., Djuve A. B., Innvandrerne som skulle klare seg selv, Fafo-rapport 2013:31.

Innvandrere og norskfødte med innvandrerforeldre, 1. januar 2015, https://www.ssb.no/befolkning/statistikker/innvbef/aar/2015-03-04, 15.06.2015.

NOU: 2011:7, Velferd og migrasjon. Den norske modellens framtid.

Kivisto P. (2001), Theorizing transnational immigration: a critical review of current efforts, „Ethnic and Racial Studies", vol. 24, nr 4, s. 549-577.

Kvale S., Brinkmann S. (2009), Interwiews. Learning the Craft of Qualitative Research Interviewing, SAGE. 
Landman T., Robinson N. (2009), The SAGE Handbook of Comparative Politics, SAGE.

Nowiak W. (2011), Nordycki model ,, welfare state" w realiach XXI wieku. Dylematy wyboru i ewolucja systemu w spoleczeństwach dobrobytu - wnioski praktyczne, Poznań.

Ødegård A. M., Andersen R. K., Østeuropeisk arbeidskraft i hotell, verft, fiskeindustri og kjøttindustri, Fafo-notat 2011:21.

Schwenken H. (2005, January), „Domestic slavery” versus ,, Workers' rights”: Political mobilizations of migrant domestic workers in the European Union (Working Paper 116), University of Kassel, Centre for Comparative Immigration Studies, University of California, Kassel.

Weiss R. S. (1995), Learning from strangers. The Art and Method of Qualitative Interview Studies, The Free Press.

Internal migration within the EU and EEA vis-à-vis black labor market. An analysis of the situation of Polish immigrants living in Hordaland county

\section{Summary}

This study is the result of an international research team and concerns the functioning of Poles in the illegal labor market in Norway. The study is based on in-depth interviews conducted among Polish immigrants, living in Hordaland county, whose administrative center is the city of Bergen. It shows the nature of the labor market and the principles and motives of Poles that function on the labor market.

Key words: labor migration, Poles in Norway, undeclared work, black labor in Norway, the black economy, informal employment in Norway 
